\title{
Equilibrium line and mean annual mass balance of Finsterwalderbreen, Spitsbergen, determined by in situ and laboratory gamma-ray measurements of nuclear test deposits
}

\author{
J. F. Pinglot, M. Pourchet, B. Lefauconnier, M. Greseveur \\ Laboratoire de Glaciologie et Géophysique de l'Environnement du CNRS, 38402 Saint-Martin-d'Hères Cédex, France
}

\begin{abstract}
In order to determine the equilibrium line (EL) and the annual net mass balance over the accumulation area of Finsterwalderbreen, Spitsbergen, Svalbard (by detection of the 1962-63 radioactive peak from the 1961-62 atmospheric nuclear tests), we collected 14 ice cores, at elevations of $445-730 \mathrm{~m}$, in the springs of 1994 and 1995 . The corresponding samples were melted and filtered for laboratory gamma spectrometry. In the accumulation area, the 1962-63 radioactive layer is found well below the surface. The mean annual accumulation is not invariably related to altitude. The EL, averaged to $545 \mathrm{~m}$ a.s.l., leads to an accumulation area ratio of 0.3 and indicates a strong negative balance. The $584 \mathrm{~Bq} \mathrm{~m}^{-2}$ mean ${ }^{137} \mathrm{Cs}$ deposition rate (1954-74 nuclear tests) for eight ice cores in the accumulation area is nearly twice the $340 \mathrm{~Bq} \mathrm{~m}^{-2}$ mean Svalbard value obtained from six other glaciers (at time of deposition).

An in situ gamma-ray detector was lowered down each borehole, and ${ }^{137}$ Cs levels were recorded. The counting rate is proportional to the apparent deposition rate and the specific activity. The laboratory measurements perfectly match the in situ determinations. In the ablation area, a dust layer and the associated nuclear test deposits are concentrated close to the bare ice surface of the glacier, under the winter snow layer and present maximum ${ }^{137} \mathrm{Cs}$ and ${ }^{210} \mathrm{~Pb}$ contents. The dust layer acts like a filter for radioactive materials removed from the glacier and its basin by melting and water flow. The original specific activities and deposition rates at a given location are enhanced by adsorption of additional radioactivity on the dust particles. A linear relationship exists between ${ }^{137} \mathrm{Cs}$ and ${ }^{210} \mathrm{~Pb}$ deposition rates. This process is almost constant for all studied ice cores. The apparent ${ }^{137} \mathrm{Cs}$ deposition rate for seven ice cores in the ablation area is $465 \mathrm{~Bq} \mathrm{~m}^{-2}$ (at date of measurement: 1 July 1995).
\end{abstract}

\section{INTRODUGTION}

Finsterwalderbreen is a surge-type glacier, with a polythermal regime, in a quiescent phase since its last surge around 1900 (Liestøl, 1969; Nixon and others, 1985; Hagen and others, 1993). The glacier is located in Spitsbergen at $77^{\circ} 26^{\prime} \mathrm{N}, 15^{\circ} 15^{\prime} \mathrm{E}$. It is $11 \mathrm{~km}$ long, has a $44.5 \mathrm{~km}^{2}$ surface, and ends on a moraine. It has been chosen as a test site to be investigated under EU project EV5V-CT93-0299: "Investigations of glacier surges: measurements and modelling of ice dynamics in Svalbard, European Arctic" (Fig. 1).

The aim of the present study is to estimate the recent net mass balance of the glacier and to determine the equilibrium line (EL), as well as the ${ }^{137} \mathrm{Cs}$ and ${ }^{210} \mathrm{~Pb}$ fallout levels. In the accumulation area the detection well below the surface of a reference radioactive peak corresponding to the atmospheric thermonuclear tests conducted in 1961-62, at sites including Novaya Zemlya, Russia $\left(71-73^{\circ} \mathrm{N}, 55^{\circ} \mathrm{E}\right)$ (Aarkrog and others, 1994), and deposited in 1962-63, can be used to determine the net accumulation (Lefauconnier and others, 1994). ${ }^{210} \mathrm{~Pb}$ (21.3 years half-life), of natural atmospheric origin, is the daughter of the rare gas isotope ${ }^{222} \mathrm{Rn}$, from the ${ }^{238} \mathrm{U}$ series.

During the 1994 and 1995 spring seasons, in the accumu- lation area and close to the estimated EL, at elevations of 445-730 $\mathrm{m}$ a.s.l. (Fox and Nuttall, in press), we made 13 ice cores with a light electromechanical drill (denoted F2, F3, F4, F5, F6, F7, F8, F9, F10, F11b, F12, F13 and F14, with depths ranging from a few meters up to $30 \mathrm{~m}$ ), and collected samples from a pit (F1lt) (Table 1). The locations of the cores were plotted on an accurate map by Fox and Nuttall (in press), based on a 1990 air photograph (Fig. 1). After density measurement, the snow samples $(25 \mathrm{~cm}$ mean length) were sealed in plastic bags. All ice cores consist of superimposed ice, even in the accumulation area. Just under the winter layer, the snow density rapidly increases to 0.9 . Then, in the base camp close to the glacier, the samples were melted and filtered through ion-exchange resin paper (Delmas and Pourchet, 1977), in order to conduct high-resolution gamma spectrometry at the laboratory in France.

In the ablation area, melting and water run-off take place in summer. Natural and artificial radioactive deposits are concentrated in a dust layer just under the winter snow layer, and represent an accumulation of dust and particles over many years (Pourchet and others, in press). For ice cores collected close to the EL, the original specific activities and deposition rates are enhanced by subsequent adsorption of additional radioactivity. Directly in the field, a gamma- 
Table 1. Ice core locations, winter layer thicknesses, accumulation rates and total ${ }^{137}$ Cs deposition rates from thermonuclear tests (at the time of deposition)

\begin{tabular}{|c|c|c|c|c|c|c|c|}
\hline \multirow[t]{2}{*}{ Station } & \multirow{2}{*}{$\begin{array}{l}\text { Altitude } \\
\text { ma.s.l. }\end{array}$} & \multicolumn{2}{|c|}{ Coordinates } & \multirow{2}{*}{$\begin{array}{l}\text { Winter layer } \\
\text { mw.e. }\end{array}$} & \multirow{2}{*}{$\begin{array}{c}\text { 1962-63 layer } \\
\text { mw.e. }\end{array}$} & \multirow{2}{*}{$\begin{array}{c}\text { Annual mass balance } \\
\text { m w.e. year }^{-1}\end{array}$} & \multirow{2}{*}{$\begin{array}{l}{ }^{137} \mathrm{Cs} \\
\text { Bq m }\end{array}$} \\
\hline & & lat. N & long. E & & & & \\
\hline F2 & 668 & $77^{\circ} 25^{\prime} 46^{\prime \prime}$ & $15^{\circ} 18^{\prime} 12^{\prime \prime}$ & 1.67 & $5.52-7.31$ & $0.12-0.18$ & 464 \\
\hline F3 & 607 & $77^{\circ} 26^{\prime} 11^{\prime \prime}$ & $15^{\circ} 17^{\prime} 52^{\prime \prime}$ & 1.50 & $7.96-8.32$ & $0.21-0.23$ & $>278$ \\
\hline F4 & 610 & $77^{\circ} 25^{\prime} 59^{\prime \prime}$ & $15^{\circ} 13^{\prime} 21^{\prime \prime}$ & 1.01 & $2.33-3.29$ & $0.04-0.07$ & $>572$ \\
\hline F5 & 557 & $77^{\circ} 26^{\prime} 17^{\prime \prime}$ & $15^{\circ} 14^{\prime} 24^{\prime \prime}$ & 1.32 & $4.74-5.42$ & $0.11-0.13$ & 712 \\
\hline F6 & 513 & $77^{\circ} 26^{\prime} 38^{\prime \prime}$ & $15^{\circ} 14^{\prime} 53^{\prime \prime}$ & 1.01 & 1.992 .20 & $0.03-0.04$ & 418 \\
\hline F7 & 500 & $77^{\circ} 26^{\prime} 56^{\prime \prime}$ & $15^{\circ} 12^{\prime} 21^{\prime \prime}$ & 0.60 & nd & 0 & nd \\
\hline F8 & 525 & $77^{\circ} 26^{\prime} 29^{\prime \prime}$ & $15^{\circ} 15^{\prime} 35^{\prime \prime}$ & 0.27 & nd & 0 & nd \\
\hline F9 & 535 & $77^{\circ} 26^{\prime} 44^{\prime \prime}$ & $15^{\circ} 19^{\prime} 26^{\prime \prime}$ & 0.38 & nd & 0 & nd \\
\hline F10 & 700 & $77^{\circ} 25^{\prime} 55^{\prime \prime}$ & $15^{\circ} 19^{\prime} 18^{\prime \prime}$ & 0.45 & nd & 0 & 262 \\
\hline F11 & 585 & $77^{\circ} 26^{\prime} 24^{\prime \prime}$ & $15^{\circ} 19^{\prime} 03^{\prime \prime}$ & 0.56 & nd & nd & 1022 \\
\hline $\mathrm{F} 12$ & 586 & $77^{\circ} 25^{\prime} 58^{\prime \prime}$ & $15^{\circ} 15^{\prime} 17^{\prime \prime}$ & 0.53 & $7.64-8.11$ & $0.22-0.24$ & $>1196$ \\
\hline $\mathrm{F} 13$ & 484 & $77^{\circ} 26^{\prime} 56^{\prime \prime}$ & $15^{\circ} 15^{\prime} 06^{\prime \prime}$ & 0.77 & $11.40-12.16$ & $0.33-0.36$ & $>776$ \\
\hline F14 & 413 & $77^{\circ} 27^{\prime} 41^{\prime \prime}$ & $15^{\circ} 15^{\prime} 18^{\prime \prime}$ & 0.71 & nd & 0 & nd \\
\hline
\end{tabular}

*F2-F6, 1993-94; F7-F14, 1994-95.

ray detector was lowered down each borehole for determination of this highly radioactive layer, prior to the laboratory measurements.

\section{IN SITU AND LABORATORY GAMMA-RAY MEASUREMENTS}

An in situ gamma-ray detector (NaI $(\mathrm{Tl})$ ) was lowered down each borehole, and ${ }^{137} \mathrm{Cs}$ contents (energy window: 405-880 keV) were recorded at successive depths (Pinglot and Pourchet, 1989), with a $5 \mathrm{~cm}$ depth resolution. As the

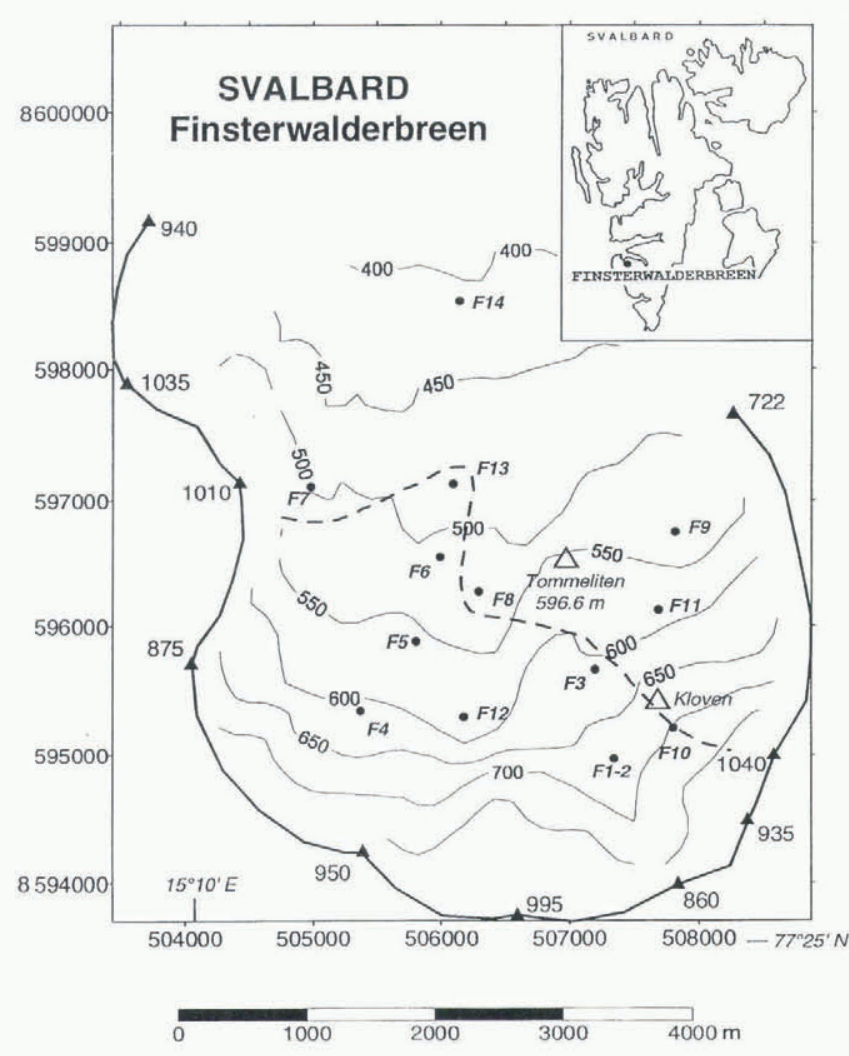

Fig. 1. Map of Finsterwalderbreen with proposed zone for the equilibrium line (dashed line), drainage basin (thick line), ice cores (F1-F14) and altitudes ( $m$ a.s.l.). depth increases, the cosmic-ray signal decreases. Just below the winter layer, the counting rate (integral of counts in the energy window; $5 \mathrm{mn}$ counting time) rapidly increases and shows a clear maximum at stations F7-F1lb and F14, whereas it is not detectable at stations F12 and F13 (situated in the accumulation area as discussed below) (Fig. 2).

On corresponding ice-core samples, high-resolution gamma spectrometry was conducted at the laboratory with a high-purity, $\mathrm{N}$-type germanium detector $(20.6 \%$ relative efficiency) used with a low specified background. It was mounted with an anti-Compton annulus which combines a 9 in $\times 8$ in and a 3 in $\times 3$ in plug of $\mathrm{NaI}(\mathrm{Tl})$ scintillators (Pinglot and Pourchet, 1994). This type of detector exhibits excellent efficiency, even down to energies as low as $46.52 \mathrm{keV}\left({ }^{210} \mathrm{~Pb}\right)$. The absolute efficiency curve from $40 \mathrm{keV}$ to $2.6 \mathrm{MeV}$ was established using standard solutions (LMRI, Amersham, NBS) and quantitative analysis software (db Gamma from Canberra Electronique Company). The detection threshold levels for ${ }^{210} \mathrm{~Pb}$ and ${ }^{137} \mathrm{Cs}$ were 25 and $4 \mathrm{mBq}$, respectively (Pinglot and Pourchet, 1995).

Gamma spectrometry on samples perfectly matches the in situ determinations, showing maximum ${ }^{137}$ Cs contents at the same depths, as well as maximum ${ }^{210} \mathrm{~Pb}$ contents (Fig. 2; Table 2). The counting rate of the in situ detector is proportional $\left(r^{2}=0.90\right)$ to the ${ }^{137} \mathrm{Cs}$ deposition rate and the specific activity (Fig. 3). In order to determine the sensitivity of the detector, the measurement from F7 was removed. The corresponding radioactive layer was too narrow $(0.12 \mathrm{~m})$, and the detector response led to an underestimate of both the activity ( 3 instead of $10 \mathrm{~Bq} \mathrm{~kg}^{-1}$ ) and the deposition $\left(600\right.$ instead of $1100 \mathrm{~Bq} \mathrm{~m}^{-2}$ ) for ${ }^{137} \mathrm{Cs}$.

The detector sensitivity is 0.4 counts s ${ }^{-1}$ per $\mathrm{Bq} \mathrm{kg}^{-1}$. This value is lower than previous determinations $\left(1.43\right.$ counts s $^{-1}$ per $\mathrm{Bq} \mathrm{kg}^{-1}$ ) (Pinglot and Pourchet, 1989), for similar energy windows (430-440 to $730-880 \mathrm{keV})$. This difference may be due to higher density of the ice at Finsterwalderbreen $(0.86-$ $0.92)$.

\section{${ }^{137}$ CS FALLOUT FROM THERMONUGLEAR TESTS IN THE ACCUMULATION AREA}

The in situ gamma-ray detector was used to make measurements in the estimated accumulation area of Finster- 

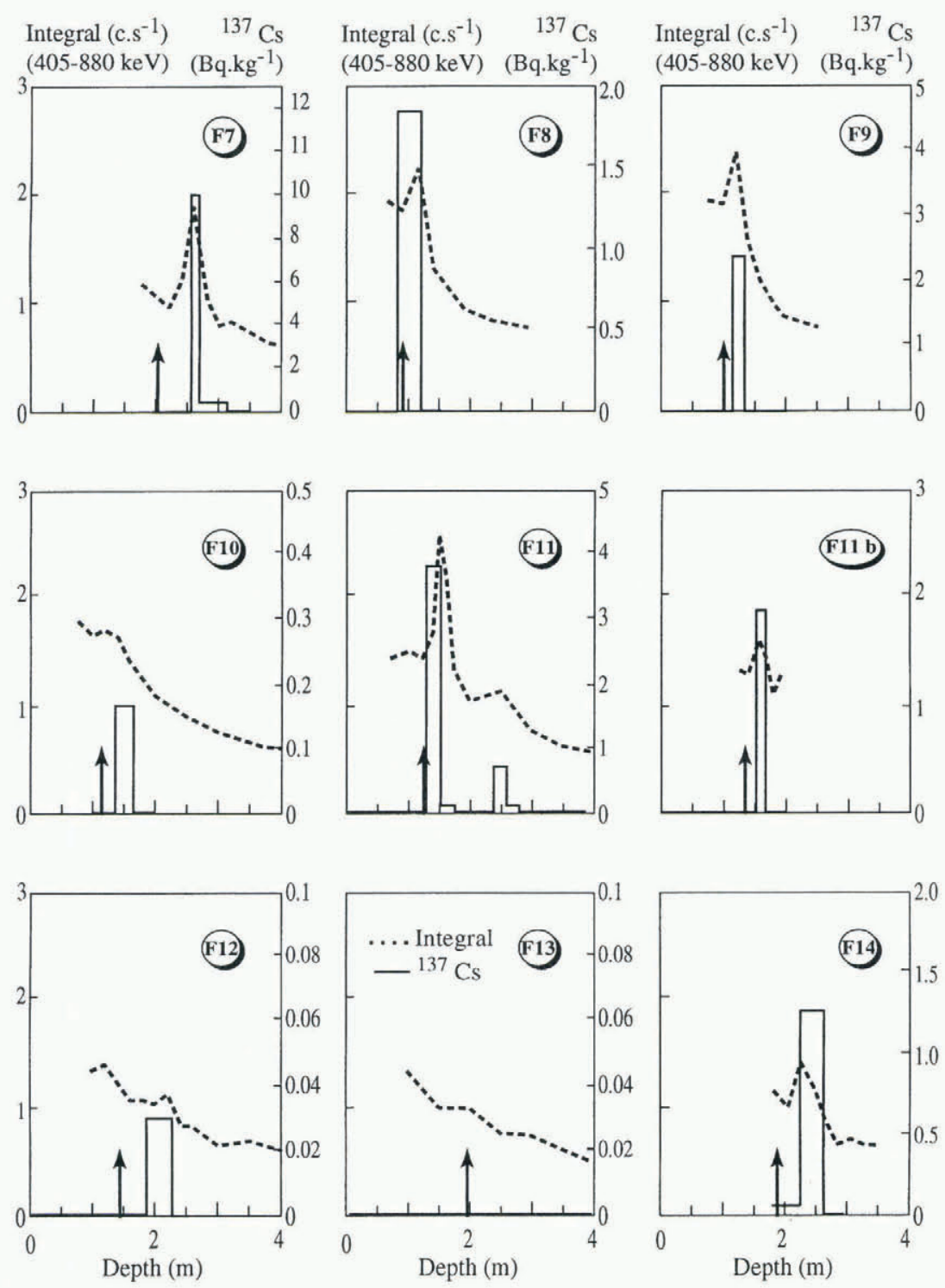

Fig. 2. In situ gamma-ray (dashed line) and ${ }^{137} \mathrm{Cs}$ (solid line) measurements vs depth for nine ice cores in the ablation area, with winter snow layer ( arrow).

walderbreen in order to determine the 1962-63 layer, down to the bottom of ice cores F10-Fl3. These direct measurements in the field are well correlated with laboratory determinations: no, or very weak, ${ }^{137} \mathrm{Cs}$ peak in F10; peaks at 9.5 , 10 and $15 \mathrm{~m}$, respectively, for F11 (narrow peak), F12 and F13
(Fig. 4). From the in situ and laboratory gamma-ray measurements, F12 (with a very weak ${ }^{137} \mathrm{Cs}$ signal) and F13 clearly belong to the accumulation area.

In the accumulation area of six glaciers over Svalbard (showing a clear densification feature), assuming that no

Table $2 .{ }^{137} \mathrm{Cs}$ and ${ }^{210} \mathrm{~Pb}$ activities and deposition rates of the dust layer, under the winter snow layer (at the date of measurement: 1 July 1995)

\begin{tabular}{|c|c|c|c|c|c|c|c|c|c|c|}
\hline \multirow[t]{3}{*}{ Station } & \multicolumn{4}{|c|}{ Depth (dust layer) } & \multirow[t]{2}{*}{ Winter layer } & \multicolumn{3}{|c|}{${ }^{137} \mathrm{Cs}$} & \multicolumn{2}{|c|}{${ }^{210} \mathrm{~Pb}$} \\
\hline & Top & Bottom & Top & Bottom & & & & & & \\
\hline & \multicolumn{2}{|c|}{ m snow } & \multicolumn{2}{|c|}{ mw.e. } & $\mathrm{m}$ snow & $\mathrm{mBqkg}^{-1}$ & $\mathrm{Bqm}^{-2}$ & counts s $^{-1}$ & $\mathrm{mBq} \mathrm{kg}^{-1}$ & $\mathrm{Bqm}^{-2}$ \\
\hline F7 & 2.61 & 2.73 & 1.1 & 1.21 & 2.04 & 10027 & 1103 & 1.11 & 5214 & 574 \\
\hline F8 & 0.8 & 1.2 & 0.27 & 0.4 & 0.8 & 1844 & 240 & 0.79 & 735 & 96 \\
\hline F9 & 1.17 & 1.36 & 0.51 & 0.68 & 1.05 & 2397 & 408 & 0.87 & 2180 & 371 \\
\hline F10 & 1.66 & 1.96 & 0.80 & 1.06 & 1.14 & 168 & 44 & 0.2 & 385 & 100 \\
\hline F11 & 1.28 & 1.5 & 0.56 & 0.75 & 1.28 & 3779 & 718 & 1.33 & 2319 & 441 \\
\hline Fllb & 1.53 & 1.67 & 0.78 & 0.9 & 1.28 & 2039 & 245 & 0.44 & 1448 & 174 \\
\hline Fllt & 1.42 & 1.78 & 0.68 & 1 & 1.28 & 601 & 192 & & 441 & 141 \\
\hline $\mathrm{F} 12$ & 1.85 & 2.26 & 0.88 & 1.23 & 1.42 & 30 & 10 & 0.25 & 116 & 41 \\
\hline $\mathrm{F} 13$ & 1.96 & 2.3 & 0.77 & 0.93 & 1.96 & 0 & 0 & 0 & 0 & 0 \\
\hline F14 & 2.26 & 2.64 & 1.05 & 1.33 & 1.81 & 1257 & 352 & 0.54 & 1300 & 364 \\
\hline
\end{tabular}


Counting rate (counts. $\mathrm{s}^{-1}$ )

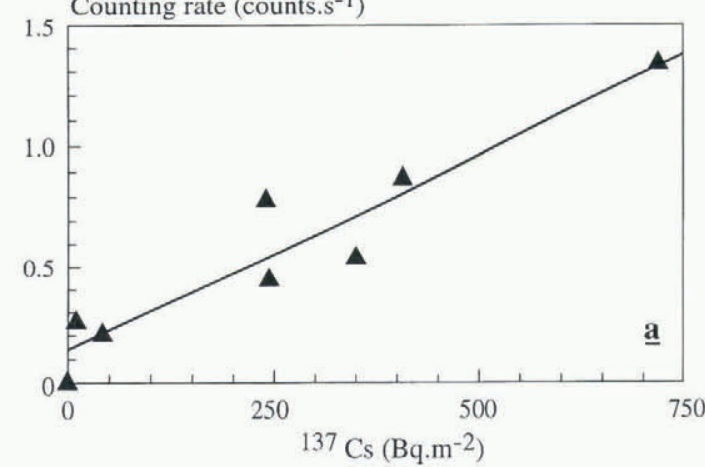

Counting rate (counts. $\mathrm{s}^{-1}$ )

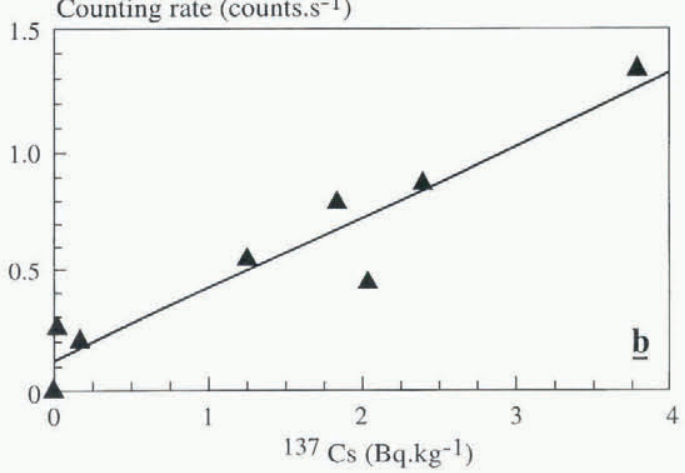

Fig. 3. Counting rate of the gamma-ray detector vs the deposition rate (a) and ${ }^{1.37}$ Cs specific activity $(b)$.

radioactivity is lost by water flow, the mean ${ }^{137} \mathrm{Cs}$ fallout from the atmospheric thermonuclear tests (1954-74) reached $340 \mathrm{~Bq} \mathrm{~m}^{-2}$ (110 $\mathrm{Bq} \mathrm{m}^{-2}$ standard deviation) at the time of deposition (Pinglot and others, 1994).

In the accumulation area of Finsterwalderbreen, with superimposed ice, the $584( \pm 304) \mathrm{Bq} \mathrm{m}^{-2}$ mean value for eight ice-cores (Table 2; Fig. 4) is nearly twice the mean Svalbard value. The ${ }^{137}$ Cs deposition is greater than the original atmospheric fallout. It may indicate that additional ${ }^{137} \mathrm{Cs}$ is introduced by extra surface deposition (water flow) from higher locations on the glacier, including, then, an influence of the basin area.

Another special feature of the ${ }^{137} \mathrm{Cs}$ distribution in ice cores in the accumulation area is the presence of ${ }^{137} \mathrm{Cs}$ well below the 1962-63 maximum. In all ice cores, ${ }^{137} \mathrm{Cs}$ is found down to the bottom of the boreholes, at an estimated date well before 1954, when the first tests were conducted. Taking into account the value of the mean annual mass balance, with the assumption of no great change, the deposition date of the bottom layers in ice cores F6, F2 and F4 is at least 1900; likely about 1915 at F5 and 1950 at F3, F12 and Fl3.

This suggests, due to melting and percolation (Ambach and others, 1989), the possible transportation of radioactive isotopes along the grain boundaries, or the presence of many microfractures, or crevasses, all over the glacier surface.

\section{MEAN ANNUAL AGGUMULATION AND EQUILI- BRIUM LINE}

The mean annual accumulation is computed over 31 or 32 years $\left({ }^{137}\right.$ Cs fallout from $1962-63$ to 1993 or 1994). The 1962-63 maximum was estimated from the ${ }^{137}$ Cs profile, taking into account the most probable slight vertical trans- port due to melting, as described above. This net mass balance varies independently with altitude (Fig. 5). It is maximum at F13 (0.34 m w.e.) at $484 \mathrm{~m}$ a.s.l., and exhibits lower values at F3 and F12 (0.23 mw.e.) at 607 and $586 \mathrm{ma}$ a.s.l., respectively. However, the mass balance is highly variable at a given altitude. It can be as low as zero for altitudes of $445-700 \mathrm{~m}$. The EL of Finsterwalderbreen is not represented by a constant altitude line but can be located roughly in a zone as illustrated in Figure 1.

There exists, from the surrounding basin area (900$1000 \mathrm{~m}$ maximum altitude) a central zone down to $460 \mathrm{~m}$ altitude where annual accumulation occurs. We measured the thickness of the winter snow layer with a rigid stick. It is maximum along this axis $(0.77 \mathrm{~m}$ w.e. at F13 for winter 1994-95). Ablation determination with stakes (Nuttall and others, 1997) shows a similar pattern, with no ablation at F9 between the summers of 1994 and 1995. This may be due to winter snow topographic features in relation to Erdmannberget summit $(1035 \mathrm{~m})$ and Tommeliten nunatak (597 m).

Concerning our study of 12 Svalbard glaciers, the mean ELA varies from $340 \mathrm{~m}$ (Amundsenissen) to $750 \mathrm{~m}$ (Gruvfonna and Kronebreen) (Pourchet and others, in press). With an ELA averaged to $545 \mathrm{~m}$ a.s.l., the accumulation area ratio $(\mathrm{AAR})$ of Finsterwalderbreen is 0.3. This indicates a strong negative net balance.

\section{${ }^{137}$ Gs AND ${ }^{210} \mathrm{~Pb}$ DEPOSITION RATES IN THE ABLATION AREA}

In situ $\left({ }^{137} \mathrm{Cs}\right)$ and laboratory $\left({ }^{137} \mathrm{Cs}\right.$ and $\left.{ }^{210} \mathrm{~Pb}\right)$ gamma spectrometries were conducted in the seven ice cores and their samples, in the ablation area (Fig. 2; Table 2).

The dust layer corresponding to the ablation surface of the glacier, under the winter snow layer, represents an accumulation over many years. The ${ }^{137} \mathrm{Cs}$ deposition rate at the time of measurement, 1 July 1995, varies from 0 (in the accumulation area, for locations higher than the EL) to $1103 \mathrm{~Bq} \mathrm{~m}^{-2}$ (station F7, in the ablation area) (Fig. 2). In the ablation area, radioactivity values are those given at the time of measurement, as we do not know the exact initial deposition location.

The ${ }^{210} \mathrm{~Pb}$ deposition rate ranges from 0 to $574 \mathrm{~Bq} \mathrm{~m}^{-2}$. A linear relationship $\left(r^{2}=0.90\right)$ exists between ${ }^{137} \mathrm{Cs}$ and ${ }^{210} \mathrm{~Pb}$ deposition rates (Fig. 6). This means that the process of concentration of radioactive materials is the same for a constant natural deposition $\left({ }^{210} \mathrm{~Pb}\right)$ and for transient events like the atmospheric thermonuclear tests of $1954-74\left({ }^{137} \mathrm{Cs}\right)$. In the ablation area, close to the EL of Finsterwalderbreen, the ${ }^{137} \mathrm{C}$ s mean deposition is even higher than in the accumulation area. The mean ${ }^{137} \mathrm{Cs}$ deposition for seven ice cores for this dust layer is $465 \mathrm{Bqm}^{-2}$, compared to 292 and $170 \mathrm{~Bq} \mathrm{~m}^{-2}$, respectively (values not corrected to the time of deposition, in the accumulation areas of Finsterwalderbreen and from six Svalbard ice cores (Pinglot and others, 1994). This shows a strong ${ }^{137} \mathrm{Cs}$ concentration. This increase in ${ }^{137} \mathrm{Cs}$ deposition reinforces the previously mentioned extra deposition due to water flow and infiltration at the glacier surface during the summer season (at F7 the deposit is $1103 \mathrm{~Bq} \mathrm{~m}^{-2}$ ). This dust layer, by a subsequent adsorption, acts like a filter for radioactive materials removed from the basin (a soil sample from Tommeliten nunatak showed ${ }^{137} \mathrm{Cs}$ activity). 

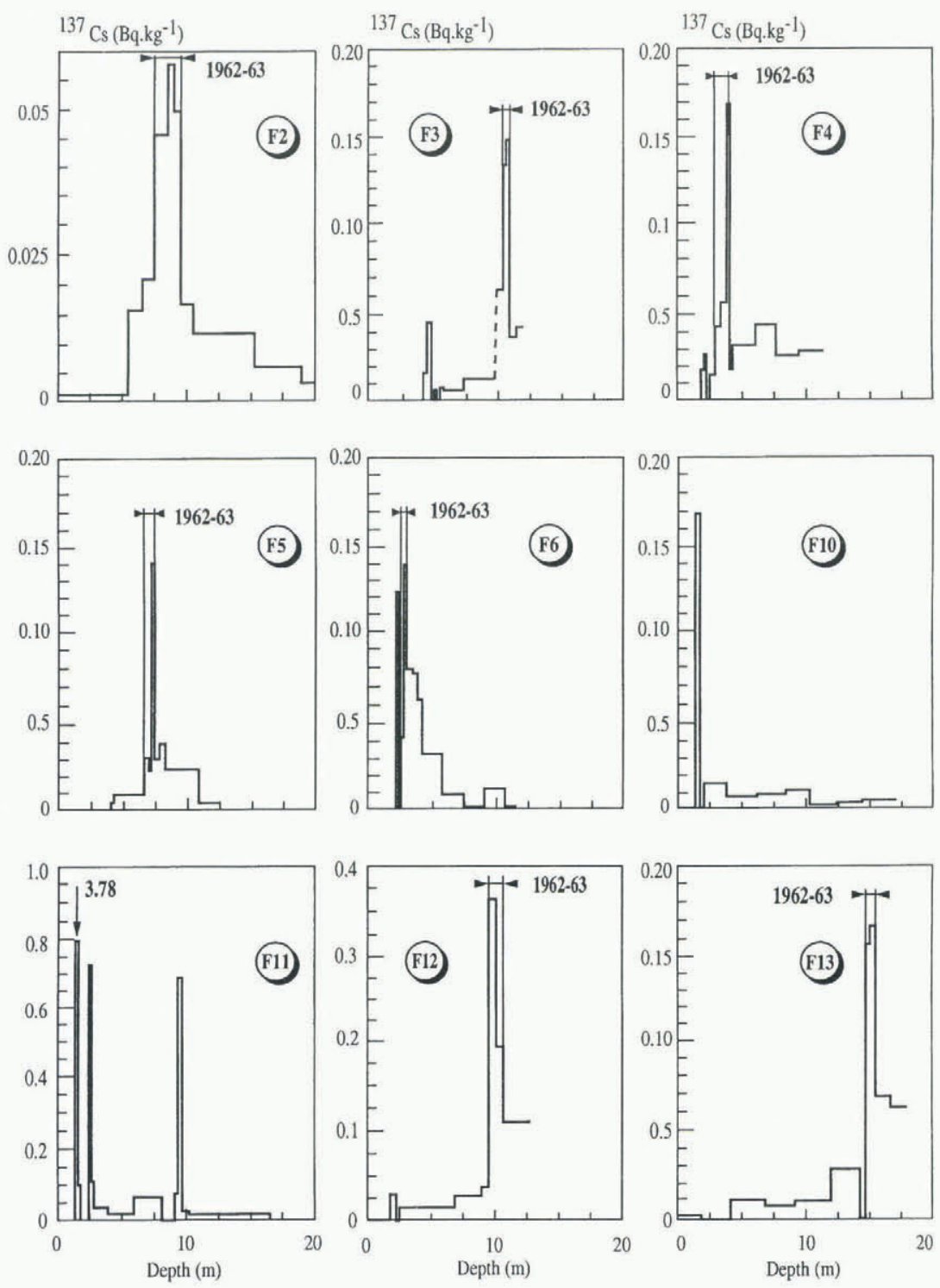

Fig. 4. ${ }^{137}$ Cs vs depth for nine ice cores in the accumulation area, with estimated 1962-63 thermonuclear test maximum.

The mean 1993-94 and 1994-95 winter depositions for ${ }^{210} \mathrm{~Pb}$ for all studied ice cores on Finsterwalderbreen were 62 and $29 \mathrm{~Bq} \mathrm{~m}^{-2}$, respectively. As much as ten times this value is found in the dust layer (even without half-life correction). Ice cores recovered close to the EL exhibit concentrations of ${ }^{137} \mathrm{Cs}$ and ${ }^{210} \mathrm{~Pb}$ which are clearly present in the dust layer. This process allows the location and mapping of the ablation area and EL zone on Finsterwalderbreen, as described above.

Analysis of the profile at F10, together with a small amount of ${ }^{137} \mathrm{Cs}\left(42 \mathrm{~Bq} \mathrm{~m}^{-2}\right)$ indicates that F10 is located in the accumulation area, with a mean annual mass balance close to zero (Fig. 4).

Large water run-off deeply influences the deposition of particles, as demonstrated at F1l. Two ice cores (F1l and Fllb, $5 \mathrm{~m}$ apart) and a pit (Fllt) (Figs 2 and 4) show a great variability of ${ }^{137} \mathrm{Cs}$ and ${ }^{210} \mathrm{~Pb}$ depositions in the dust layer, from 192 to $718 \mathrm{~Bq} \mathrm{~m}^{-2}$ for ${ }^{137} \mathrm{Cs}$, and from 141 to $441 \mathrm{~Bq} \mathrm{~m}^{-2}$ for ${ }^{210} \mathrm{~Pb}$ (the winter layer shows a $17 \mathrm{~Bq} \mathrm{~m}^{-2}{ }^{210} \mathrm{~Pb}$ deposition). F1l belongs to the set of ice cores showing strong ${ }^{137} \mathrm{Cs}$ and ${ }^{210} \mathrm{~Pb}$ contents of the dust layer under the winter snow, but also a continuous ${ }^{137} \mathrm{Cs}$ distribution down to $10 \mathrm{~m}$ depth. The $0.69 \mathrm{~Bq} \mathrm{~kg}^{-1}$ maximum ${ }^{137} \mathrm{Cs}$ content between 9.34 and $9.64 \mathrm{~m}$, which is also a maximum ${ }^{210} \mathrm{~Pb}$ content $(0.44 \mathrm{~Bq}$ $\mathrm{kg}^{-1}$ ) does not represent $1962-63$, but rather a layer with a concentration of isotopes due to melting and redistribution.

\section{CONCLUSIONS}

In the accumulation area of Finsterwalderbreen, with superimposed ice, the detection well below the surface of a radioactive peak corresponding to the atmospheric thermo-

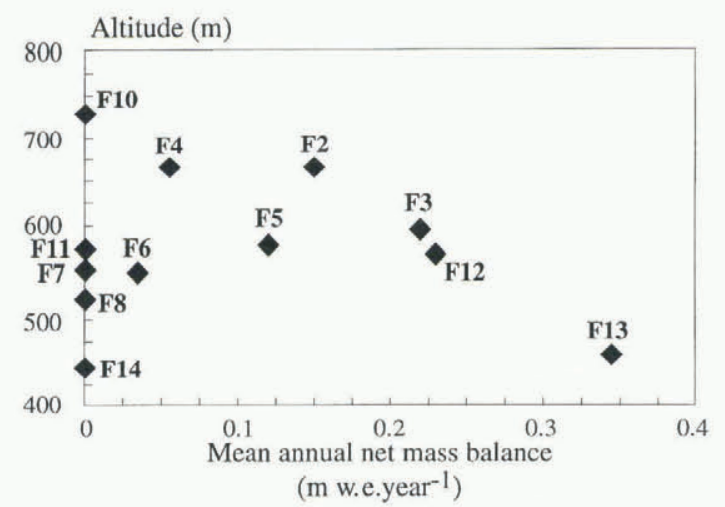

Fig. 5. Mean annual net mass balance vs altitude at Finsterwalderbreen. 
$210 \mathrm{~Pb}\left(\right.$ Bq. $\left.\mathrm{m}^{-2}\right)$

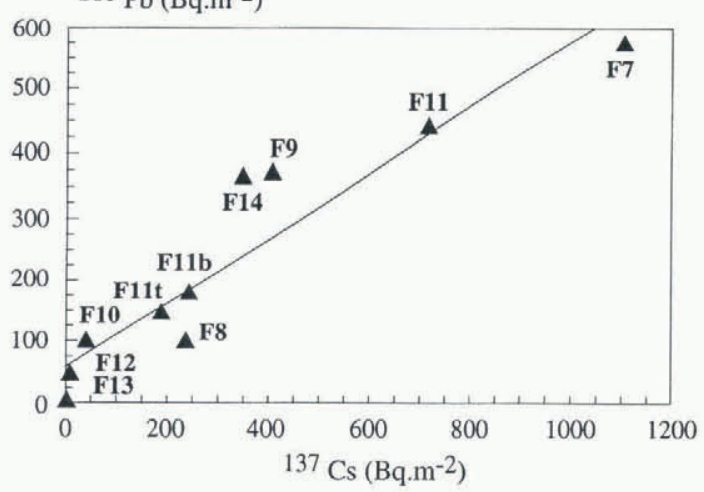

Fig. 6. ${ }^{210} \mathrm{~Pb}$ vs ${ }^{137} \mathrm{Cs}$ deposition rates.

nuclear tests conducted in 1961-62 can be used to determine the mean annual net accumulation. This accumulation varies independently with respect to altitude, with a maximum of $0.34 \mathrm{~m}$ w.e. However, due to infiltration, ${ }^{137} \mathrm{Cs}$ is found down to the bottom of the boreholes, at estimated dates well before 1954 .

In the ablation area, all artificial radioactive deposits are concentrated in the ice surface layer just under the winter snow. On corresponding ice-core samples, gamma spectrometry perfectly matches the in situ determinations, showing maximum ${ }^{137} \mathrm{Cs}$ contents at the same depths. The counting rate of the in situ detector is proportional to the ${ }^{137} \mathrm{Cs}$ deposition rate and the specific activity. A linear relationship exists between ${ }^{137} \mathrm{Cs}$ and ${ }^{210} \mathrm{~Pb}$ deposition rates. This dust layer acts like a filter for radioactive materials removed from the basin. In the ablation area, close to the EL, the ${ }^{137} \mathrm{Cs}$ apparent mean deposition in the dust layer is higher than in the accumulation area, 465 vs $292 \mathrm{~Bq} \mathrm{~m}^{-2}$, making it possible to locate and map the ablation area and the EL zone. With an ELA averaged to $545 \mathrm{~m}$ a.s.l., the AAR is 0.3 , indicating a strong negative net balance for Finsterwalderbreen.

\section{ACKNOWLEDGEMENTS}

This study was funded by EU project No. EV5V-CT930299, and fieldwork during spring 1994 and 1995 was jointly financed by the Institut Français pour la Recherche et la Technologie Polaires (project No. 265-294) and the Fondation Franco-Norvégienne. The logistic support from Norwegian Polar Institute at Longyearbyen was greatly appreciated. The authors would like to thank Drs J. O. Hagen, J. A. Dowdeswell, A.-M. Nuttall and R. S. Ødegård for helpful discussions and $\mathrm{Mr} \mathrm{C}$. Vincent for the map of the upper part of Finsterwalderbreen. The comments from Dr D. Peel and an anonymous reviewer were greatly appreciated.

\section{REFERENCES}

Aarkrog, A., Y. Tsaturov and G. G. Polikarpov. 1994. Sources of environmental radioactive contamination in the former U.S.S.R. Luxembourg, European Commission. (Radiation Protection 71.)

Ambach, W., W. Rehwald, M. Blumthaler, H. Eisner and P. Brunner. 1989. Vertical dispersion of Chernobyl-fallout by meltwater in a temperate Alpine glacier. Geogr. Fís. Din. Quat., 12(2), 151-153.

Delmas, R. and M. Pourchet. 1977. Utilisation de filtres échangeurs d'ions pour l'étude de l'activité Beta globale d'un carottage glaciologique. International Association of Hydrological Sciences Publication 118 (Symposium at Grenoble 1975 - Isotopes and Impurities in Snow and Ice), 159-163.

Fox, A. J. and A.-M. Nuttall. In press. Photogrammetry as a research tool for glaciology. Photogramm. Rec.

Hagen, J. O., O. Liestøl, E. Roland and T. Jørgensen. 1993. Glacier atlas of Svalbard and Jan Mayen. Nor. Polarinst. Medd. 129.

Lefauconnier, B., J. O. Hagen, J. F. Pinglot and M. Pourchet. 1994. Massbalance estimates on the glacier complex Kongsvegen and Sveabreen, Spitsbergen, Svalbard, using radioactive layers. F. Glaciol., 40(135), 368-376.

Liestøl, O. 1969. Glacier surges in west Spitsbergen. Can. 7. Earth Sci., 6(4), Part 2, 895-897.

Nixon, W. A. and 6 others. 1985. Applications and limitations of finite element modeling to glaciers: a case study. 7. Geophys. Res, 90 (B13), 11,303-11,311.

Nuttall, A.-M., J. O. Hagen and J. A. Dowdeswell. 1997. Quiescent-phase changes in velocity and geometry of Finsterwalderbreen, a surge-type glacier in Svalbard. Ann. Glaciol., 24 (see paper in this volume).

Pinglot, J. F. and M. Pourchet. 1989. Détermination du bilan glaciaire en zone d'accumulation par mesures in situ de la radioactivité due à Tchernobyl. C. R. Acad. Sci. (Paris), Ser. 2, 309(4), 365-370.

Pinglot, J.F. and M. Pourchet. 1994. Spectrométrie gamma à très bas niveau avec anti-Compton $\mathrm{NaI}$ ( $\mathrm{Tl}$ ), pour l'étude des glaciers et des sédiments. CEA Note, 2756, 291-296.

Pinglot, J. F. and M. Pourchet. 1995. Radioactivity measurements applied to glaciers and lake sediments. Sci. Total Environ., 173-174, 211-223.

Pinglot, J. F. and 8 others. 1994. Natural and artificial radioactivity in the Svalbard glaciers. 7. Environ. Radioactivity, 25, 161-176.

Pourchet, M., B. Lefauconnier, J. F. Pinglot and J. O. Hagen. In press. Mean net accumulation of ten glacier basins in Svalbard estimated from detection of radioactive layers in shallow ice cores. Z Gletscherkd. Glazialgeol. 